\title{
Fluid geochemistry and seismic activity in the period 1998-2002 at Turrialba Volcano (Costa Rica)
}

\author{
Franco Tassi $\left({ }^{1}\right)$, Orlando Vaselli $\left({ }^{1}\right)$, Vilma Barboza $\left({ }^{2}\right)$, Erick Fernandez $\left({ }^{2}\right)$ and Eliecer Duarte $\left({ }^{2}\right)$ \\ (') Dipartimento di Scienze della Terra, Università degli Studi di Firenze, Italy \\ ${ }^{(2)}$ Volcanological and Seismological Observatory, Universidad Nacional, Heredia, Costa Rica
}

\begin{abstract}
Turrialba Volcano, located in Central-Southern Costa Rica, has been characterized, since the last period of eruptive activity in 1884-1886, by a weak and discontinuous fumarolic activity in the western area of its summit. During the 1998-2002 period, fumaroles discharging from central and West craters were collected for chemical analyses of major and trace gas compounds, ${ }^{13} \mathrm{C} /{ }^{12} \mathrm{C}$ in $\mathrm{CO}_{2}$ and ${ }^{18} \mathrm{O} /{ }^{16} \mathrm{O}$ and $\mathrm{D} / \mathrm{H}$ (in one fumarolic condensate), isotopic ratios. Geophysical measurements (seismic activity and ground deformation), monitored in the same period, were compared to geochemical data to define the status of the volcanic system. Chemical and isotopic characteristics of fumaroles of Turrialba Volcano seem to be related to interaction processes between a magmatic source and a shallower hydrothermal aquifer. Since February 1997, seismicity at Turrialba Volcano gradually increased, while since August 2001 new fumaroles start to discharge from a new fracture system located in the area between central and West craters. Since September 2001, strong compositional changes of gas discharges have been recorded at central crater. These occurrences are possibly due to variations in the permeability of the conduit system feeding the fumaroles. Heat pulse episodes from a magmatic source have possibly caused the increase of vapour pressure at depth and, consequently, favoured the uprising of the magmatic fluids toward the surface. The observed evolution of chemical and physical parameters suggests that to forecast a possible renewal of the volcanic activity in the near future a full program of both geochemical and geophysical surveillance must be provided at Turrialba Volcano.
\end{abstract}

Key words volcanic gases - volcanic hazard-geochemical monitoring - geophysical monitoring Turrialba Volcano - Costa Rica

\section{Introduction}

Turrialba $(10.03 \mathrm{~N}, 83.77 \mathrm{E})$ is an active stratovolcano belonging to the Holocene «Cordillera Central» volcanic belt and is located at about 35 and $15 \mathrm{~km}$ from the towns of San José and Carta-

Mailing address: Dr. Franco Tassi, Departimento di Scienze della Terra, Università degli Studi di Firenze, Via G. La Pira, 4, 50121, Firenze, Italy; e-mail: francot@steno.geo.unifi.it go, respectively (fig. 1). This region is part of the central Mountain Range Conservation Area and includes seven volcanic edifices. It was colonized by the Indians of the Oriental Huetar Kingdom and later by the Spaniards. Originally this volcano was named «Torre Alba» (White Tower) by the Spaniards, due to the presence of a large plume that looked like an enormous white tower. Since its last eruption (16 September 1864), Turrialba Volcano has been characterized by a discontinuous fumarolic activity. A small plume, visible from the immediate surroundings of the volcano, has occasionally been reported. In the last decade, the presence of continuous weak fumarolic discharges has been observed.

In the present study, the results of a geochemical monitoring carried out from 1998 to 2002 


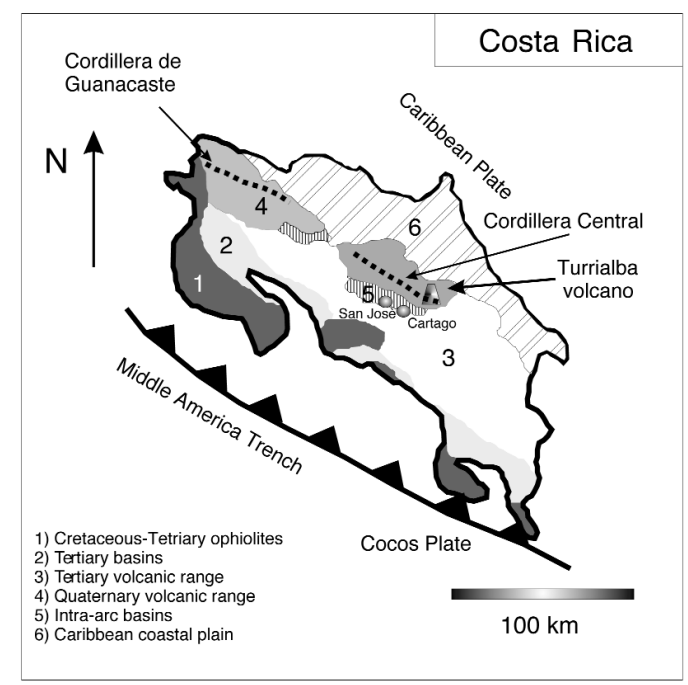

Fig. 1. Schematic geological map of Costa Rica. The Middle America Trench, the Caribbean Plate, the Cocos Plate, the Cordillera de Guanacaste volcanic arc, the Cordillera central volcanic arc and the location of the Turrialba Volcano are reported.

on the fumaroles of the summit craters are described and discussed. Data from a geophysical monitoring of the seismic activity, carried out by the Volcanological and Seismological Observatory of the National University of Costa Rica, are also included. Thus, the main goals of this work are: i) to investigate the origin of the fumarolic discharges; ii) to evaluate the evolution in time of both chemical parameters and seismic activity and iii) to assess the status of activity of the volcanic system.

\section{Geological and volcanological background}

Costa Rica consists of six main geologic provinces (Castillo, 1984): 1) Cretaceous-Middle Tertiary ophiolitic suite; 2) Tertiary basins; 3 ) Tertiary volcanic ranges; 4) Active Quaternary volcanic ranges; 5) Intra-arc basins; 6) Caribbean coastal plain (fig. 1). The active Quaternary volcanic ranges comprise the Cordillera de Guanacaste to NW and the Cordillera central to SE (fig. 1). The volcanic activity in Costa Rica in the last 25000 years has been characterized mainly by phreatic and phreato-magmatic eruptions, with rare plinian events (Alvarado et al., 1992) and is related to the subduction of the Cocos plate underneath the Caribbean plate (e.g., Johnston and Thorkelson, 1997 and references therein), with a subduction angle of about $30^{\circ}$ (Protti et al., 1995).

Turrialba is a composite stratovolcano $(3,325$ meters a.s.1.) and belongs to the Cordillera central where two more active volcanoes with historical eruptions are present: Irazu and Poàs. This volcanic range also includes Platanar, Congo and Barva volcanoes. Historic eruptive activity of Turrialba dates back to 1723, 1847, 1853, 1855, 1861 and 1864-1866 (Castillo, 1984). They were probably small phreatic eruptive events, but very little is currently known about these volcanic activities. The last eruption (1864-1866) was characterized by the emission of large volumes of ashes that, during the period of major activity (February 1866), extended up to Nicaragua (OvSICORI-UNA, 1998). The West crater on the North-western side of the volcano summit (fig. 2) was formed during this eruptive event. In 1920 and in the period 1950-1960 local newspapers reported that large columns of vapour were observed from the city of Cartago, showing that episodes of strong fumarolic emission have occurred several times in the last century. Turrialba summit presently hosts three NESW oriented craters: East, central and West

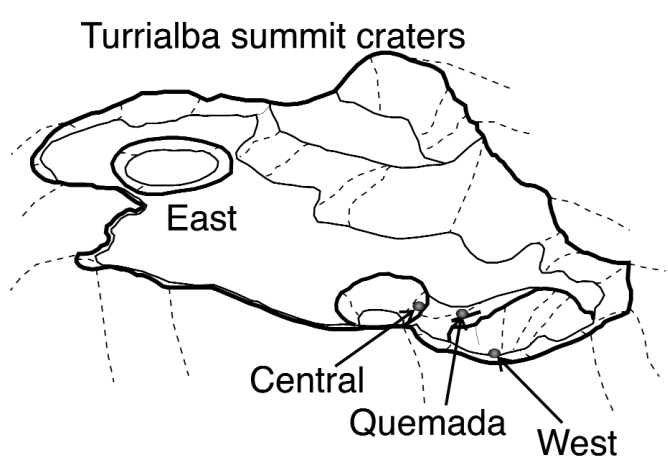

Fig. 2. Map of the summit craters of Turrialba Volcano with the location of principal, central and Quemada fumaroles. 
craters (fig. 2). Sulphur deposits of the central crater had been exploited till the end of the 80's. The age of the craters decreases from East to West and the central and West craters currently have fumarolic emissions.

\section{Sampling and analytical procedures of gas discharges}

Gas discharge sampling points are shown in fig. 2. Fumaroles from both the central and West craters are characterised by a relatively low flux. They seep out, mainly as diffuse emissions, from areas of few tens of square meters and marked by an intense rock alteration. Gas sampling of the West crater fumarole started in February 1998, whereas that of the central crater in February 1999, due to the fact that previously the flux of this gas discharge was too low and diffuse. The Quemada fumarolic field, formed during summer 2001 but sampled only in April 2002, discharges from a large fracture (about $30 \mathrm{~m}$ long and $5 \mathrm{~m}$ wide) located between the West and central craters (fig. 2) where burning effects on the nearby vegetation were produced by the hot gas emission.

Gas sampling was performed with a titanium tube inserted into the gas outlets. Gases were convoyed, through pyrex glass dewars, into pre-weighted and pre-evacuated $50 \mathrm{ml}$ thorion-tapped vials to which $20 \mathrm{ml}$ of a $0.15 \mathrm{M}$ $\mathrm{Cd}(\mathrm{OH})_{2}$ and $4 M \mathrm{NaOH}$ solution was previously added. Here, acid gases $\left(\mathrm{CO}_{2}, \mathrm{SO}_{2}, \mathrm{H}_{2} \mathrm{~S}\right.$, $\mathrm{HCl}$, and $\mathrm{HF}$ ) dissolve into the alkaline solution, while the unabsorbed gases $\left(\mathrm{N}_{2}, \mathrm{O}_{2}, \mathrm{CO}\right.$, $\mathrm{He}, \mathrm{H}_{2}, \mathrm{CH}_{4}, \mathrm{Ar}$, Ne and light hydrocarbons) concentrate in the head-space. Sulphur from $\mathrm{H}_{2} \mathrm{~S}$ immediately precipitate as $\mathrm{CdS}$ (Montegrossi et al., 2001). Major and trace inert gas compounds were analysed with Shimadzu 15A and Shimadzu 14A gas-chromatographs equipped with TCD (Thermal Conductivity Detector) and FID (Flame Ionisation detector), respectively. $\mathrm{CO}$ was determined, as $\mathrm{CH}_{4}$, after its conversion at $400^{\circ} \mathrm{C}$ (Shimadzu MTN-1 methanizer), using $\mathrm{H}_{2}$ as carrier gas to allow the $\mathrm{CO}$ $\mathrm{CH}_{4}$ Fischer-Trops reaction (in presence of Shimalite-Ni acting as catalyser). The complete separation of $\mathrm{Ar}-\mathrm{O}_{2}$ and $\mathrm{He}-\mathrm{Ne}-\mathrm{H}_{2}$ peaks was performed at low temperature (about $0^{\circ} \mathrm{C}$, obtained with a Shimadzu CRG-15 cryogenic equipment) by using a $9 \mathrm{~m}$ length molecular sieve column. $\mathrm{CO}_{2}$, trapped in the caustic solution of the sampling vials, was determined by acid titration with $0.5 \mathrm{M} \mathrm{HCl}$, while $\mathrm{SO}_{2}, \mathrm{H}_{2} \mathrm{~S}$, $\mathrm{S}^{0}$ and $\mathrm{HCl}$ abundances were performed by ionchromatography (Dionex DX100 ion-chromatograph), as described in Montegrossi et al. (2001). HF contents in the condensates (collected at the «bulbe» temperature by the gentle dropping from glass tubes wrapped with paper tissue) were determined by potentiometry with a specific electrode. Analytical precision was $<1 \%$ for major components and $<5 \%$ for minor and trace compounds.

${ }^{13} \mathrm{C}^{12} \mathrm{C}$ ratios of $\mathrm{CO}_{2}$ (expressed as $\%$ PDB) were determined with a Finningan Delta $\mathrm{S}$ mass spectrometer after the standard procedures of extraction and purification of the gas mixtures (Evans et al., 1998). The reproducibility of $\delta$-values for $\mathrm{C}$ is $\pm 0.1^{\%} \%$. $\delta^{18} \mathrm{O}$ and $\delta \mathrm{D}$ values (expressed as $\%$ SMOW) were determined with a Finningan Delta $\mathrm{S}$ mass spectrometer after equilibrating the waters with $\mathrm{CO}_{2}$ and after the reaction of $10 \mathrm{ml}$ of water with $0.3 \mathrm{~g}$ of pure $\mathrm{Zn}$ at $500^{\circ} \mathrm{C}$, respectively (Vaselli et al., 1997, 1998).

\section{Gas chemistry and isotopic composition}

The analytical results for chemical and isotopic composition of the fumarolic discharges from the West crater (10 gases sampled from February 1998 to April 2002), central crater (6 gases sampled from February 1999 to April 2002) and Quemada fracture (sampled in April 2002) are shown in tables I and II. Fumarole temperatures ranged between 86 and $92^{\circ} \mathrm{C}$, with no remarkable differences among the three sites of gas discharges. Gas chemical composition is characterized by the predominance of $\mathrm{H}_{2} \mathrm{O}$ (up to $980000 \mu \mathrm{mol} / \mathrm{mol}$ ) and $\mathrm{CO}_{2}$ (up to $580000 \mu \mathrm{mol} / \mathrm{mol}$ ), with less $\mathrm{N}_{2}$, $\mathrm{H}_{2} \mathrm{~S}, \mathrm{HCl}$, and $\mathrm{H}_{2}$ contents $(6700,2400,570$ and $428 \mu \mathrm{mol} / \mathrm{mol}$, respectively). $\mathrm{S}^{0}, \mathrm{HF}, \mathrm{CO}$, $\mathrm{He}, \mathrm{Ne}, \mathrm{CH}_{4}$ and light hydrocarbons are present as trace compounds. Ar contents are $<11$ $\mu \mathrm{mol} / \mathrm{mol}$, indicating a very limited air-contamination on the composition of gas samples. 


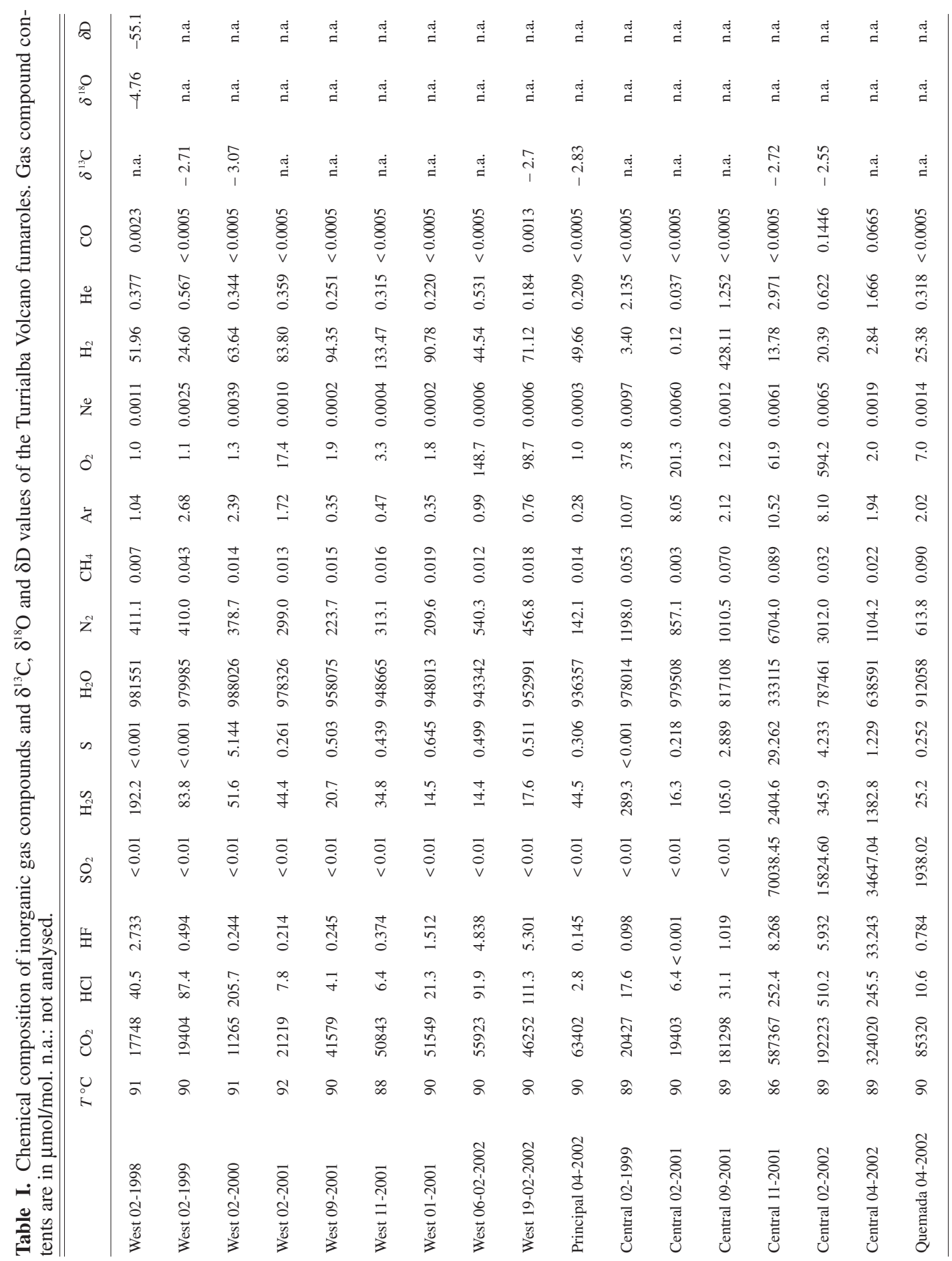




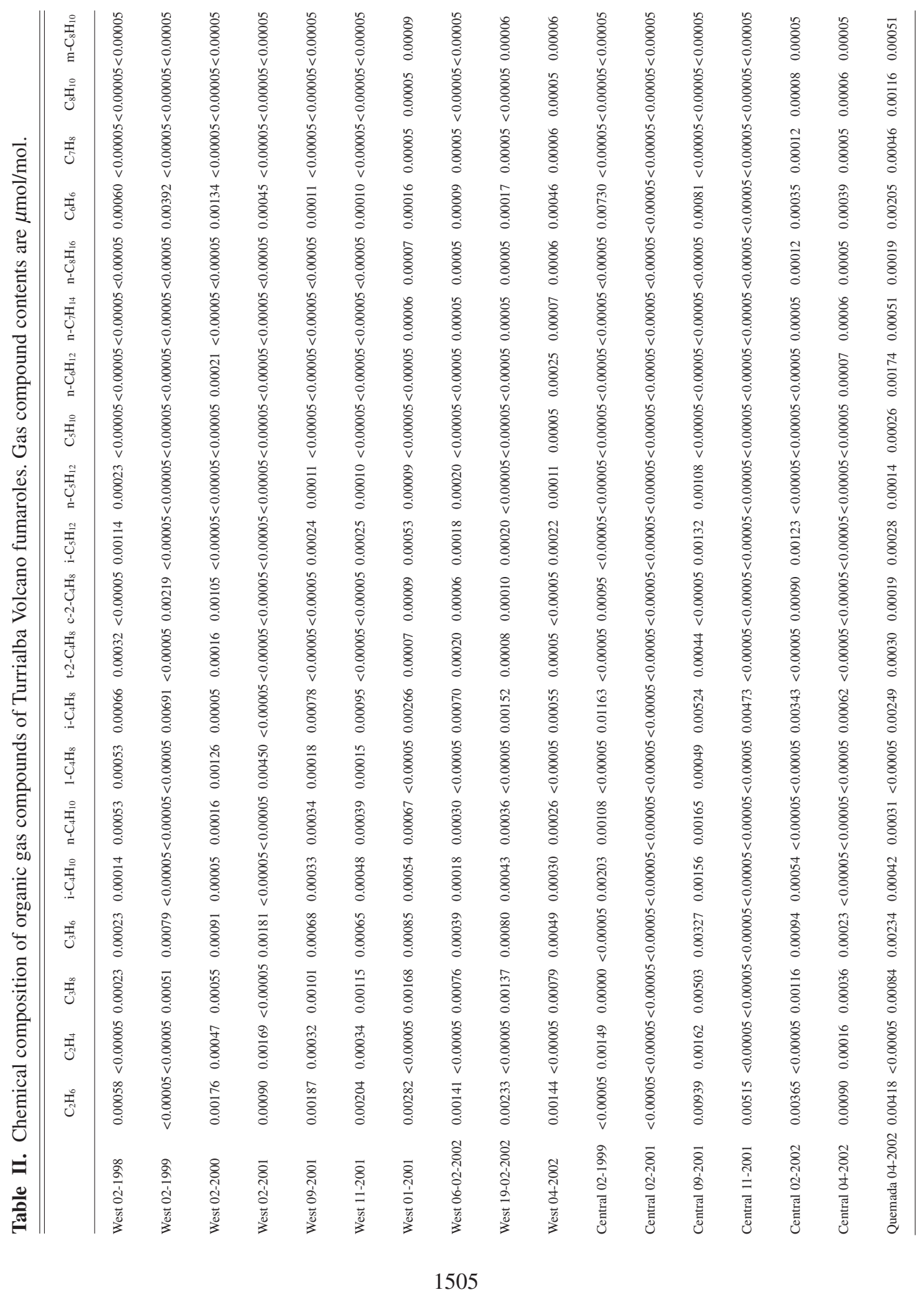


The wide variability of $\mathrm{O}_{2}$ contents (ranging from 1 to $594 \mu \mathrm{mol} / \mathrm{mol}$ ) is possibly related to its partial consumption during fluid circulation, since it is involved in redox reactions with both the other gas compounds and the hosting rocks. $\mathrm{SO}_{2}$ in the West gas samples is below the detection limit $(<0.01 \mu \mathrm{mol} / \mathrm{mol})$. On the contrary, since November 2001, $\mathrm{SO}_{2}$ has been detected in the central fumarole (up to 70000 $\mu \mathrm{mol} / \mathrm{mol}$ ). Quemada fumarole shows an intermediate composition between the West and the central fumaroles (tables I and II).

$\delta^{13} \mathrm{C}$ in $\mathrm{CO}_{2}$ range between -3.1 and $-2.7 \%$ PDB, with no remarkable difference among the different gas discharges. $\delta^{18} \mathrm{O}$ and $\mathrm{D} / \mathrm{H}$ ratios, analysed in the condensate of the gas sample collected in 1998 at the West fumarole, are -4.76 and $-55.1 \%$ SMOW, respectively.

\section{Discussion}

\subsection{Origin of gases}

The chemical composition of Turrialba gas discharges is relatively enriched in the less soluble acidic compounds, such as $\mathrm{CO}_{2}$ and $\mathrm{H}_{2} \mathrm{~S}$, although the presence of $\mathrm{HCl}, \mathrm{SO}_{2}$ and $\mathrm{HF}$ (table I) indicates that, at least partly, the magmatic signature still remains. The relative abundances of $\mathrm{N}_{2}$, Ar and $\mathrm{He}$ are plotted in fig. 3, where basaltic magmatism («mantle»), convergent plate boundaries («andesite») and crust fields («crust») are also reported (Giggenbach, 1996). $\mathrm{N}_{2} / \mathrm{Ar}$ ratios of all the samples (up to 640) are higher than that in the air (83), suggesting a non-atmospheric origin for $\mathrm{N}_{2}$, probably partly released from subducted sedimentary material, as commonly observed for gases collected in areas of convergent active tectonics (Giggenbach, 1996), although He relative contents seem to differ sensitively from the typical volcanic arc gas compositions (Sano and Wakita, 1985; Sano et al., 1987). As shown in fig. 4, Ne/Ar ratios are between those of air and Air Saturated Water (ASW), suggesting a common atmospheric source for these two compounds. Concerning the organic gas fraction, up to 20 different hydrocarbon compounds pertaining to the $\mathrm{C}_{2}-\mathrm{C}_{8}$ species (the so-called «light hydrocarbons») were detected. Relative

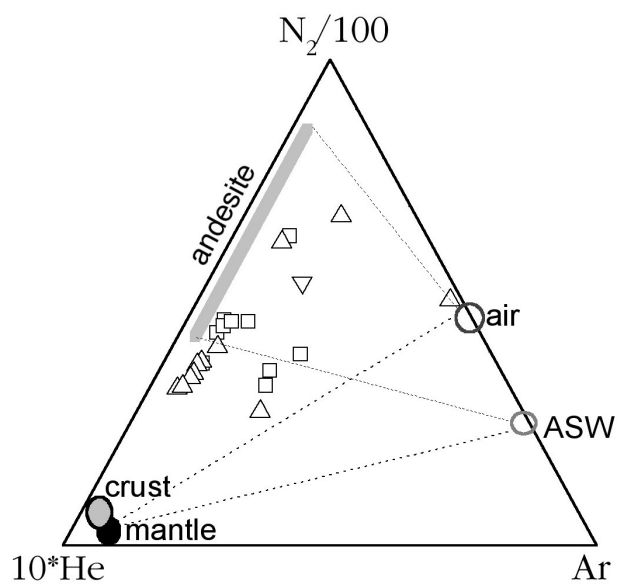

Fig. 3. $\mathrm{N}_{2} / 100-\mathrm{Ar}-10 \mathrm{He}$ ternary diagram for the Turrialba fumaroles. Basaltic magmatism («mantle»), convergent plate boundaries («andesite») and crust fields («crust») are also reported (Giggenbach, 1996). ASW: Air Saturated Water open squares: Principal crater fumarole; open up triangles: central crater fumarole; open down triangles: Quemada fumarole.

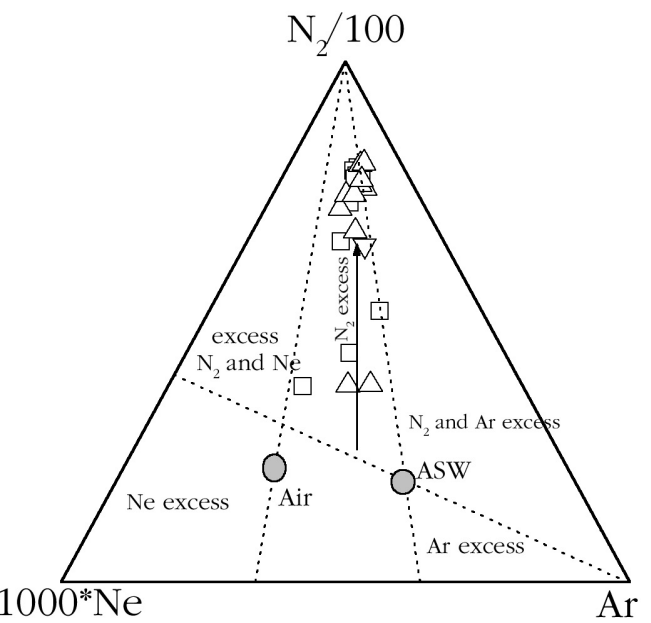

Fig. 4. $A r-\mathrm{N}_{2} / 100-1000 \mathrm{Ne}$ ternary diagram for the Turrialba fumaroles. Air and Air Saturated Water (ASW) compositions were reported. Symbols as in fig. 3 . 


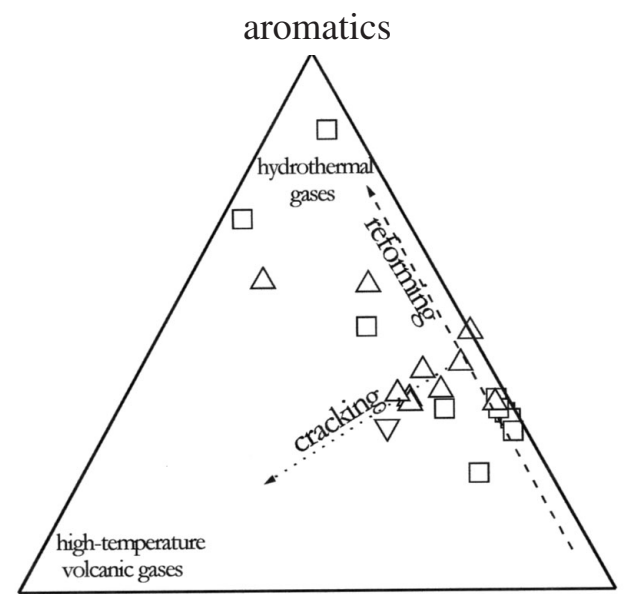

alkanes

alkanes

Fig. 5. Alkanes-aromatics-alkanes ternary diagram for the Turrialba fumaroles. Symbols as in fig. 3 .

high contents of hydrocarbons pertaining to both aromatic and alkene groups were systematically observed in fumaroles from volcanic areas and geothermal fields with respect to those measured in gases from quiescent volcanism (Capaccioni et al., 1993). The composition of the organic gas fraction can be referred to the occurrence of two chemical processes: $i$ ) catalytic reforming reactions and ii) thermal cracking reactions (Capaccioni et al., 1995). The catalytic reforming process is typical in hydrothermal environment, while cracking reactions are considered negligible at $T<300^{\circ} \mathrm{C}$. At Turrialba Volcano production of hydrocarbon gas species is probably controlled by catalytic-type oxidation and hydration reactions (Seewald, 2001), which may lead to the formation of both alkane and aromatic gas compounds. However, a notable influence of kinetic processes, through the breakage of carboncarbon bonds, produces a general reduction of the molecular weight and possibly leads to the generation of alkene gas compounds.

Preliminary analytical results of $\mathrm{R} / \mathrm{Ra}$ (where $\mathrm{R}$ is the ${ }^{3} \mathrm{He} /{ }^{4} \mathrm{He}$ ratio in the sample and $\mathrm{Ra}$ is the ${ }^{3} \mathrm{He} /{ }^{4} \mathrm{He}$ ratio in the air: $1.34 \times 10^{-6}$ ) values are up to 7.5 and suggest that Turrialba gas discharges are strongly influenced by a magmatic component (Vaselli et al., 2002). Values of $\delta^{13} \mathrm{C}$ (table I; fig. 6) suggest that $\mathrm{CO}_{2}$ derived from a mixing between a possible mantle source and a sedimentary end-member (Giggenbach et al., 1993; Rollison, 1993; Sano et al., 1997). As shown in fig. 7, where the «andesitic water» area (Taran et al., 1989; Giggenbach, 1992) is also reported, a condensate sample of West fumarole (sampled in 1998) has isotopically heavier $\delta^{18} \mathrm{O}$ and $\mathrm{D} / \mathrm{H}$ ratios than those of the meteoric water (Lachniet and Patterson, 2002), considering that the altitude of the recharge area is at about $3500 \mathrm{~m}$. This supports the hypothesis that Turrialba fumaroles were recharged by significant contribution of magmatic water. From $X a=\left(\delta g-\delta_{m}\right) /\left(\delta a-\delta_{m}\right)$ (Giggenbach and Corrales, 1992), where $\delta g$ represent the isotopic ratio of ${ }^{18} \mathrm{O} /{ }^{16} \mathrm{O}$ or $\mathrm{D} / \mathrm{H}, \delta a$ is the corresponding ratios of the «andesitic waters» and $\delta_{m}$ is the isotopic composition of the local meteoric recharge, a fraction of about $30 \%$ of «andesitic water» was estimated.

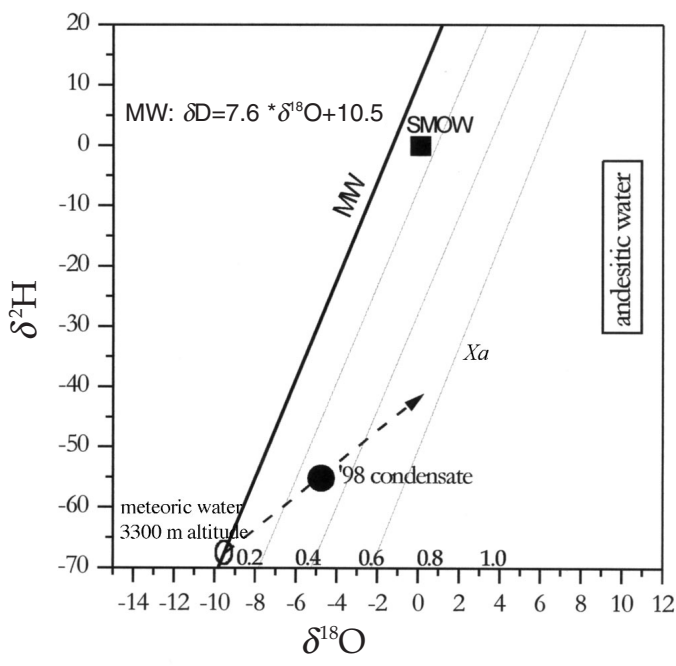

Fig. 6. $\delta{ }^{18} \mathrm{O}-\delta \mathrm{D}$ diagram for the condensate of the central crater fumarole at Turrialba Volcano. The SMOW field, the «Andesitic water» field (Taran et $a l ., 1989)$ and the Local Meteoric Water Line (Lachniet and Patterson, 2002), were reported. Symbols as in fig. 3. 
As a consequence, the chemical composition of the gas discharges at Turrialba Volcano is likely to be related to the interaction between hot fluids ascending from the deep magmatic system, and a shallow aquifer. The latter is able to lower the temperature of the uprising fluids (temperatures of gas discharges are below $92^{\circ} \mathrm{C}$ ) and dissolve the deep-originated acid species.

\subsection{Temporal evolution of gas composition}

During the period the present study was carried out (February 1998-April 2002), major chemical changes in the central fumarole were detected, whilst the West fumarole did not suffer any substantial compositional modification (tables I and II). The newly formed fracture system (Quemada) released gases with a chemical composition approaching that of the central fumarole. In spite of the measured changes in gas composition, no variations of the outlet temperatures of all the fumaroles were observed. On the basis of the data gathered, the chemical evolution of the fumarolic discharges at Turrialba Volcano can be summarised as follows:
1) Between February 1998 and February 2001 gas discharges were characterised by $\mathrm{H}_{2} \mathrm{O}$ contents $>940000 \mu \mathrm{mol} / \mathrm{mol}$, minor contents of $\mathrm{CO}_{2}$ and $\mathrm{H}_{2} \mathrm{~S}$ (up to 20000 and 290 $\mu \mathrm{mol} / \mathrm{mol}$, respectively) and very low concentrations of typical high temperature compounds (up to $205,5.3,0.0023$ and $>0.01 \mu \mathrm{mol} / \mathrm{mol}$ for $\mathrm{HCl}, \mathrm{HF}, \mathrm{CO}$ and $\mathrm{SO}_{2}$, respectively).

2) In September 2001 the chemical composition of central fumarole started to change, with a dramatic increase in both $\mathrm{CO}_{2}$ and $\mathrm{H}_{2}$ contents (fig. 7c).

3) In November 2001, the same fumarole showed a further increase in $\mathrm{CO}_{2}$ (up to $587000 \mu \mathrm{mol} / \mathrm{mol}$ ), appearance of relatively high contents of $\mathrm{SO}_{2}$ (up to $70000 \mu \mathrm{mol} / \mathrm{mol}$ ), and an increase in $\mathrm{H}_{2} \mathrm{~S}, \mathrm{HCl}$ and $\mathrm{HF}$ concentrations of about one order of magnitude (from 105 to 2400,31 to 252 and 1 to $38 \mu \mathrm{mol} / \mathrm{mol}$, respectively) (fig. 7a,b).

4) In February and April 2002 significant $\mathrm{CO}$ contents were measured (up to 0.1146 $\mu \mathrm{mol} / \mathrm{mol}$ ) (table I).

The compositional evolution of central fumarole has to be related to a change of the equilibria between the hot deep source and the cold

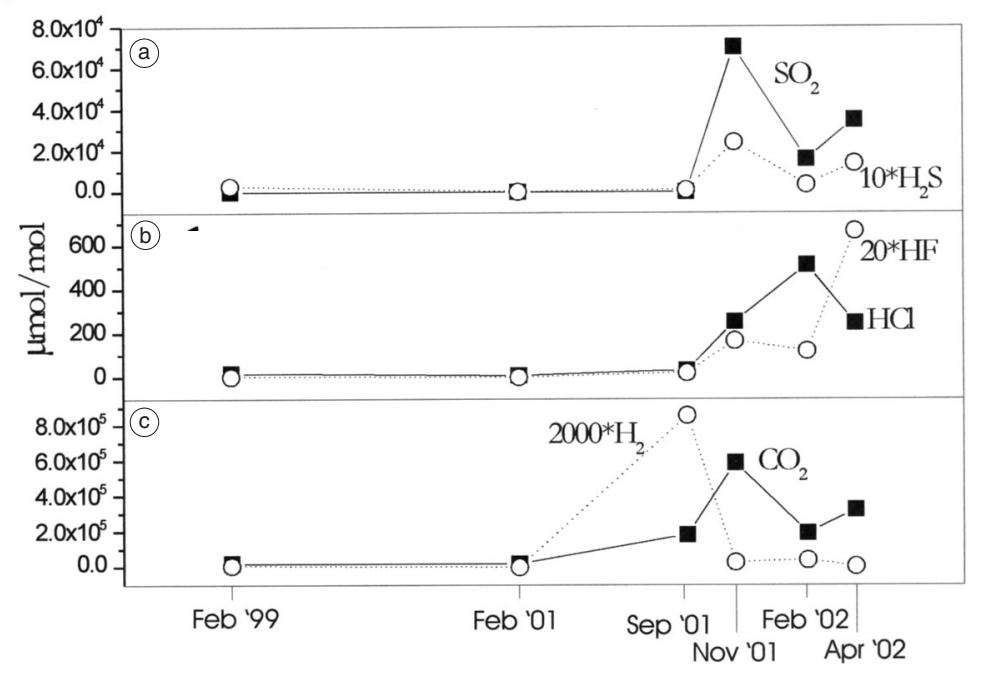

Fig. 7a-c. Temporal variations of $10 * \mathrm{H}_{2} \mathrm{~S}$ and $\mathrm{SO}_{2}(\mathrm{a}), 20 * \mathrm{HF}$ and $\mathrm{HCl}$ (b) and $\mathrm{CO}_{2}$ and $2000 * \mathrm{H}_{2}$ (c) contents for central crater fumarole at Turrialba Volcano. 
shallow liquid buffer, probably due to a «deep hot pulse» which occurred in summer 2001. The sudden increase in $\mathrm{H}_{2}$ contents recorded in September 2001 in central fumarole was possibly produced by a more effective dissociation of $\mathrm{H}_{2} \mathrm{O}$ related to the described increase of heat flux from depth. As a further consequence of the increase in the vaporization rate of the shallow aquifer, major changes in the permeability of the fracture system that feeds the fumarolic discharges occurred. This allowed the acid species such as $\mathrm{SO}_{2}, \mathrm{HCl}$ and $\mathrm{HF}$, to reach the surface, as confirmed by the composition of central crater fumarole after November 2001. On the contrary, the temperature continued to be buffered by the shallow system (the fumaroles remained below $90^{\circ} \mathrm{C}$, the boiling temperature of water at about $3000 \mathrm{~m}$ of altitude).

\subsection{Geothermometry}

Equilibrium temperatures calculated by $\mathrm{H}_{2} /$ Ar geothermometer (Chiodini et al., 2001) are 621 and $495^{\circ} \mathrm{C}$ for West and central fumaroles, respectively (table III). It is possible to speculate that such temperatures are consistent with thermodynamic conditions regulating the volcanic system at depth. The difference among the results obtained from the chemical composition of the two fumaroles is likely to be related to air-contamination, which particularly affected Ar contents of central gas discharge due to the low gas flux. The relatively high temperature calculated for the sample collected in September 2001 at central fumarole (about $140^{\circ} \mathrm{C}$ above the mean value; table III), is related to the previously mentioned sudden increase in $\mathrm{H}_{2}$ (table I). Differently, geothermometric calculation based on $\mathrm{CH}_{4} / \mathrm{CO}_{2}$ redox pair (Giggenbach and Goguel, 1989) indicates mean equilibrium temperatures of 868 and $963^{\circ} \mathrm{C}$ for West and central fumaroles, respectively. Since these $\mathrm{CH}_{4} / \mathrm{CO}_{2}$ temperatures are too high to correspond to realistic thermodynamic conditions at depth, they are possibly due to partial methane destruction by thermal degradation, able to modify $\mathrm{CH}_{4} / \mathrm{CO}_{2}$ ratios established through thermodynamic equilibria. This effect is more evident for the central gas samples collected after February 2001 (equilibrium tem-
Table III. Equilibrium temperatures calculated with $\mathrm{H}_{2} / \mathrm{Ar}$ and $\mathrm{CH}_{4} / \mathrm{CO}_{2}$, geothermometers for the Turrialba Volcano gases. Temperatures are in ${ }^{\circ} \mathrm{C}$.

\begin{tabular}{lcc}
\hline \hline & $\mathrm{CH}_{4} / \mathrm{CO}_{2}$ & $\mathrm{H}_{2} / \mathrm{Ar}$ \\
\hline West 02-1998 & 885 & 325 \\
West 02-1999 & 702 & 550 \\
West 02-2000 & 754 & 581 \\
West 02-2001 & 832 & 598 \\
West 09-2001 & 894 & 647 \\
West 11-2001 & 914 & 648 \\
West 01-2001 & 892 & 646 \\
West 06-02-2002 & 963 & 595 \\
West 19-02-2002 & 884 & 616 \\
West 04-2002 & 963 & 635 \\
Mean West & 868 & 621 \\
Central 02-1999 & 687 & 456 \\
Central 02-2001 & 1020 & 367 \\
Central 09-2001 & 887 & 638 \\
Central 11-2001 & 1018 & 495 \\
Central 02-2002 & 1005 & 513 \\
Central 04-2002 & 1161 & 498 \\
Mean Central & 963 & 495 \\
Quemada 04-2002 & 773 & 559 \\
\hline
\end{tabular}

perature rises up to $1161^{\circ} \mathrm{C}$ in April 2002), on which, as suggested by chemical and physical evidence, the magmatic influence on fluid chemistry is particularly high.

\subsection{Seismic activity and ground deformation}

Further information on the state of activity of Turrialba has been provided by the geophysical surveillance that started in 1990 with a single station located at the summit of the volcano. Since 1999 VDAP-USGS assistance to OVSICORIUNA has provided 4 seismic telemetric stations, including a three component short-period sta- 
tion, to improve the geophysical monitoring of the area. In the period 1990-1996, seismic activity was relatively low (0-91 events/month). In May 1996, small magnitude LP events $(M<1.6$ in the Richter scale) occurred (Fernández et al., 1996). Since February 1997 seismicity gradually has increased, up to 2000 events/month, and in October 2000 a further increase was recorded. In January 2001, late March 2001, October 2001 and October 2002, four seismic swarms characterized by hybrid (dominant frequency 2.1-3.5 Hz) and LP events (dominant frequency $<1.8 \mathrm{~Hz}$ ) with a maximum magnitude of 2.0 were detected. Determination of hypocenters located the seismic events at an estimated depth of 4-6 km, beneath a $4 \mathrm{~km}$ elongated area comprising the summit craters and the northern flank. In addition to seismic records, dry tilt measurements carried out at the «La Silvia» station located $2.5 \mathrm{~km} \mathrm{~W}$ of the volcano summit showed, between October 1996 and January 1999, an accumulated radial inflation of $28 \mu \mathrm{rad}$ (Barboza et al., 2003). The characteristics of the geophysical parameters seem to indicate the occurrence of hydrofracturaction phenomena at depth (Barboza et al., 2003), promoted by an increase in pressure due to fluid vaporization possibly triggered by an enhanced heat input, that have also caused a reduction of the efficiency of the aqueous buffer system. Eventually, at the top of the volcano, the ground deformation caused the opening of new fractures with radial and concentric direction with respect to the position of the central crater.

\section{Concluding remarks}

The evolution of the chemical composition of the fumarolic gas discharges along with the geophysical parameters suggests that a relatively high-temperature system is still active at Turrialba Volcano and major modifications of the present status of activity are occurring. The described behaviour of the volcanic system is not necessarily related to an incipient resumption of eruptive activity at Turrialba Volcano, that would eventually be preceded by further changes in gas chemistry, ground deformation and seismic signals. Moreover, previous studies on these fumarolic discharges carried out in the earlier eighties detected the presence of $\mathrm{SO}_{2}, \mathrm{H}_{2}$ and $\mathrm{CO}$ in the gas phase (Cheminée et al., 1982). This may suggest that, before the chemical changes recorded after September 2001, variations in gas chemistry of this volcanic system had already occurred. By coupling these observations with the last volcanic events, mainly phreatic eruptions, at Turrialba two different scenarios can be hypothesised: i) the increasing pressure may result in an enhanced fracturing system at the craters, that may allow a release of the accumulated energy without eruptive events; ii) the overpressure may trigger small-to-medium size phreatic eruptions. Alternatively, we can speculate that the persistence of high heat-flux from depth may cause the total consumption of the shallow aquifer. In this case, a further rapid evolution of the chemical characteristics of the fluids and a strong increase in the temperatures of the fumaroles should be detected prior to the occurrence of an eruptive event, probably characterised by a significant magmatic contribution.

In order to monitor the activity of the Turrialba volcanic system, a bi-weekly or at least monthly gas sampling collection, with an improved seismic and ground deformation surveillance, is highly recommended.

\section{Acknowledgements}

Many thanks are due to F. Bergamaschi for his help during the sampling campaign in Febraury 2001. This work was supported by the Italian Space Agency (resp. OV).

\section{REFERENCES}

Alvarado, G.E., S. Kussmaul, S. Chiesa, P.Y. Gillot, H. Appel, G. Corner and C. Rundle (1992): Resumen cronoestratigrafico de las rocas igneas de Costa Rica basado en dataciones radiometricas, J. South. Am. Earth Sci., 6 (3), 151-168.

Barboza, W., E. Fernandez, E. Duarte, W. Saenz, M. Martinez, N. Moreno, T. Marino, R. VAN DER LaAt, E. Hernandez, E. Malavassi and J. Valdes (2003): Changes in the activity of Turrialba Volcano: seismicity, geochemistry and deformation, in 8th Gas 
Workshop, IAVCEI, March-April, Nicaragua-Costa Rica

Capaccioni, B., M. Martini, F. Mangani, G. Giannini, G. NAPPI and F. PRATI (1993): Light hydrocarbons in gasemissions from volcanic areas and geothermal fields, Geochem. J., 27, 7-17.

Capaccioni, B., M. Martini and F. Mangani (1995): Light hydrocarbons in hydrothermal and magmatic fumaroles: hints of catalytic and thermal reactions, Bull. Volcanol, 56, 593-600.

CAstillo, R.M. (1984): Geologia de Costa Rica, Editorial de la Universidad de Costa Rica, San Josè, Costa Rica, pp. 188

Cheminée, J., M. Javoy and H. Delorme (1982): Temperature and Gas Data from Turrialba, 01/83 (SEAN 08:01)

Chiodini, G., L. MARINI and M. Russo (2001): Geochemical evidence for the existence of high-temperature hydrothermal brines at Vesuvio Volcano, Italy, Geochim. Cosmochim. Acta, 13, 2129-2147.

Evans, W.C., L.D. WHITE and J.B. RAPP (1998): Geochemistry of some gases in hydrothermal fluids from the southern Juan de Fuca ridge, J. Geophys. Res., 15, 305-313.

Fernández, E., E. DuARTe, V. BARboza, R. VAN DER LAAT, E. Hernandez, M. Martinez and R. SÁEnz (1996): Number of Microseismic Events Continues to Increase, 12/96 (BGVN 21:12).

Johnston, S.T. and D.J. Thorkelson (1997): Cocos-Nazca slab window beneath central America, Earth Planet. Sci. Lett., 146, 465-474.

GigGENBACH, W.F. (1992): Isotopic shifts in waters from geothermal and volcanic systems along convergent plate boundaries and their origin, Earth Planet. Sci. Lett., 113, 495-510.

GigGENBACH, W.F. (1996): Chemical composition of volcanic gases, in Monitoring and Mitigation of Volcanic Hazards, edited by M. ScARPA, R. TILling (Springer, Berlin), 221-256.

GigGENBACH, W.F. and R.S. CORRALES (1992): Isotopic and chemical composition of water and steam discharges from volcanic-magmatic-hydrothermal systems of the Guanacaste geothermal province, Costa Rica, Appl. Geochem., 7, 309-332.

GigGENBACH, W.F. and R.L. GoguEL (1989): Collection and analysis of geothermal and volcanic water and gas discharges, DSIR Chemistry, Rep. 2401.

GiggenbaCh, W.F., Y. SANo and H. Wakita (1993): Isotopic composition of helium, and $\mathrm{CO}_{2}$ and $\mathrm{CH} 4$ contents in gases produced along the New Zealand part of a convergent plate boundary, Geochim. Cosmochim. Acta, 57, 3427-3455.

LACHNiET, M.S. and W.P. PATtERSon (2002): Stable isotope values of Costa Rican surface waters, J. Hydrol., 260, 135-150.
Montegrossi, G., F. Tassi, O. Vaselli, A. Buccianti and K. Garofano (2001): Sulphur species in volcanic gases, Anal. Chem., 73, 3709-3715.

OVSICORI-UNA (1998): Report Turrialba activity, Smithsonian Institution: Global Volcanism Network Bullettin, 23/3.

Protti, M., G. Guendel and K. McNally (1995): Correlation between the age of the subducting Cocos Plate and the geometry of the Wadaty-Benioff zone under Nicaragua and Costa Rica, in Geologic and Tectonic Development in the Caribbean Plate Boundary in Southern Central America, edited by P. Mann, Geol. Soc. Am. Spec. Pap. 295, 309-326.

SANO, Y. and H. WAKITA (1985): Distribution of ${ }^{3} \mathrm{He} /{ }^{4} \mathrm{He}$ ratios and its implications for geotectonic structure of the Japanese Islands, J. Geophys. Res., 23, 109123.

SANO, Y., H. WAKITA and W.F. GIGgEnBACH (1987): Island arc tectonics of New Zealand manifested in helium isotope ratios, Geochim. Cosmochim. Acta, 51, 1855-1860.

Rollison, H. (1993): Using geochemical date. Longman Scientific and Technical, pp. 352.

SANO, Y., T. GAMO and S.N. WILLIAMS (1997): Secular variations of helium and carbon isotopes at Galeras Volcano, Colombia, in Galeras Volcano Colombia: interdisciplinary study of a Decade Volcano, edited by J. Stix, M.L. Calvache and S. N. Williams, J. Volcanol. Geotherm. Res., 77, 255-265.

SeEwald, J.S. (2001): Aqueous geochemistry of low molecular weight hydrocarbons at elevated temperatures and pressures: constraints from mineral buffered laboratory experiments, Geochim. Cosmochim. Acta, 65, $1641-1664$

TARAN, Y.A., B.G. Pokrovsky and A.D. Esikov (1989): Deuterium and oxygen-18 in fumarolic steam and amphiboles from some Kamchatka volcanoes: «andesitic waters», Dokl. Akad. Nauk SSSR, 304, 440-443.

Vaselli, O., P. Censi, D. Abbado, A. Minissale, M. PAOLIERI and F. TASSI (1997): Regolamento operativo per le analisi dei rapporti isotopici ${ }^{18} \mathrm{O} /{ }^{16} \mathrm{O}$ e ${ }^{13} \mathrm{C} /{ }^{12} \mathrm{C}$ nei carbonati, ${ }^{13} \mathrm{C} /{ }^{12} \mathrm{C}$ nella $\mathrm{CO}_{2}$ dei gas $\mathrm{e}{ }^{18} \mathrm{O} /{ }^{16} \mathrm{O}$ nelle acque, Internal Report CNR-CSMGA, 1, 1-14.

Vaselli, O., P. Censi, A. Minissale, A. Casiglia, M. PAOLIERI and F. TASSI (1998): Regolamento operativo per le analisi dei rapporti isotopici D/H nelle acque, Internal Report CNR-CSMGA, 2, 1-12.

Vaselli, O., F. Tassi, E. Fernandez, E. Duarte, V. BarBoza, G. Magro and A. Minissale (2002): Fluid geochemistry evolution at Turrialba Volcano (Costa Rica). Colloque Intl., Mt. Pelèe 1902-2002, Explosive Volcanism in Subduction Zones, 12-16 May, 2002, Ilede la Martinique (France), 90. 
